\title{
Pre-slaughter losses of broilers: effect of time period of the day and lairage time in a subtropical climate
}

\section{Perdas pré-abate de frangos de corte: efeito dos períodos diários e do tempo de espera em clima subtropical}

\author{
Frederico Márcio Corrêa Vieira ${ }^{*}$; Matheus Deniz ${ }^{2}$; \\ Iran José Oliveira da Silva3; José Antonio Delfino Barbosa Filho4; \\ Afrânio Márcio Corrêa Vieira ${ }^{5}$; Francielle Soares Gonçalves ${ }^{2}$
}

\begin{abstract}
Mortality losses of broilers during pre-slaughter operations consists of actual challenge for maintaining world leadership of Brazilian poultry industry. In relation to thermal environment and its influence on abattoirs' handling, some studies has advanced about the knowledge of these variables on poultry welfare. However, few studies was developed in subtropical conditions, considering a joint analysis of involved thermal factors. In this context, the aim of this work was to assess the mortality of broiler chickens transported throughout daily periods and submitted to different lairage time intervals. A trial was conducted in a commercial slaughterhouse at São Paulo state, during 2006. More than 13,000 loads was registered regarding broiler mortality data during pre-slaughter operations, as well as factors which had influence on losses, such as daily periods, lairage time and bioclimatic variables. Higher mortality rates of broiler transportation were registered during afternoon, around 13 birds per truck. Regarding the interaction between daily periods and lairage time at abattoir, during morning and afternoon, the mortality rate was reduced when birds were submitted to a lairage time of two hours in a controlled environment. These results showed the high level of pre-slaughter losses during hottest periods and the importance of environment control during pre-slaughter lairage of broiler chickens, with adoption of increasing time intervals when lairage environment is controlled.
\end{abstract}

Key words: Environmental science, poultry logistics, poultry production, welfare

\section{Resumo}

As perdas por mortalidade nas operações pré-abate de frangos de corte constituem-se desafios atuais na manutenção da liderança do setor avícola brasileiro no cenário mundial. Com relação ao ambiente térmico e sua influência no manejo em abatedouros, algumas pesquisas têm avançado quanto ao entendimento destas variáveis no bem-estar das aves. Entretanto, poucos estudos foram realizados em condições subtropicais, considerando a análise conjunta dos fatores térmicos envolvidos. Neste contexto, objetivou-se avaliar a mortalidade de frangos de corte, transportados ao longo dos períodos diários e submetidos aos diferentes intervalos de tempo de espera em abatedouro. A pesquisa foi conduzida em

1 Prof., Grupo de Estudos em Biometeorologia, GEBIOMET, Universidade Tecnológica Federal do Paraná, UTFPR, Dois Vizinhos, PR, Brasil. E-mail: fredericovieira@utfpr.edu.br

2 Discentes, Grupo de Estudos em Biometeorologia, GEBIOMET, UTFPR, Dois Vizinhos, PR, Brasil. E-mail: matheus-utfpr@ hotmail.com; francielle.soares92@hotmail.com

3 Prof., Núcleo de Pesquisa em Ambiência, NUPEA, Escola Superior de Agricultura Luiz de Queiroz, Universidade de São Paulo, ESALQ/USP, Piracicaba, SP, Brasil. E-mail: iranoliveira@usp.br

4 Prof., Universidade Federal do Ceará, UFC, Fortaleza, CE, Brasil. E-mail: zkdelfino@ufc.br

5 Prof., Universidade Federal de São Carlos, UFSCar, São Carlos, SP, Brasil. E-mail: fran.usp@gmail.com

* Author for correspondence 
um abatedouro comercial no Estado de São Paulo, no ano de 2006. Mais de 13 mil caminhões foram registrados quanto aos dados de mortalidade de frangos de corte durante as operações pré-abate, bem como os fatores influentes nas perdas, tais como os períodos do dia em que as aves foram transportadas, tempo de espera pré-abate e variáveis bioclimáticas. Durante o período da tarde foram registradas as maiores proporções de mortalidade durante o transporte, ou seja, em torno de 13 aves por caminhão. Quanto à interação entre períodos diários e tempo de espera em abatedouro, durante o período da manhã e tarde, a mortalidade foi menor quando as aves foram submetidas ao tempo de espera acima de duas horas em galpão climatizado. Tais resultados evidenciam o nível de perdas pré-abate por mortalidade em períodos quentes a importância da ambiência durante a espera pré-abate de frangos de corte, com a adoção de intervalos de tempo maiores quando o ambiente de espera for climatizado.

Palavras-chave: Ambiência, avicultura, bem-estar, logística avícola

\section{Introduction}

Currently, heat stress caused by high environment temperatures during pre-slaughter operations is considered to be the main obstacle in broiler production, accounting for most of death cases before the animals' arrival at the slaughterhouse (BERGOUG et al., 2013). From their earliest days, the animals are placed in the industrial production setting. This is the major hindering factor toward animal's thermal equilibrium with its surrounding environment due to high stocking density (NAZARENO et al., 2011). Therefore, broilers are subjected to pre-slaughter operations (catching, loading, transport, and lairage), which, mainly in tropical and subtropical regions, tend to increase the mortality rates during their transport between the production farm and the slaughterhouse (SARNIGHAUSEN et al., 2013; SILVA; VIEIRA, 2012).

There is insufficient information concerning the optimal procedures that would provide thermal comfort of broilers and improve their welfare. According to Silva and Vieira (2010), 40\% of deaths that occur during bird transportation are due to heat stress, excessive vibration, fasting, noise, and restrictions of the birds' natural behavior. Several other factors should be taken into consideration regarding the losses at the end of the process, such as duration of the transport, stocking density per crate, and production type, among others (NIELSEN et al., 2011).

Several studies have highlighted the main critical points related to the thermal conditions of the environment and its influence on birds' welfare during transport. Delezie et al. (2007) have studied the heat stress in birds caused by variations in stocking density in hotter and colder days, and concluded that the optimal stocking density is about seven to eight birds per crate. As for the period of transportation, most of the losses occurred during the periods with higher temperatures (SCHWARTZKOPF-GENSWEIN et al., 2012). However, the thermodynamic feature of the nighttime is temperature reduction and increase in relative humidity. Hence, the thermal gradient between the interior of the load and the external environment may lead to the birds' severe hypothermia, mainly in colder regions of the country (BARBOSA FILHO et al., 2009).

Therefore, air-conditioning plays an important role in reaching the optimal lairage time. In climate-controlled environments, these time intervals varied for more than two hours (QUINN et al., 1998). According to Vieira et al. (2013), the optimal lairage time slots range from 2 to 4 hours in a climate-controlled lairage environment at the slaughterhouse, in order to provide thermal comfort to the birds and, consequently, reduce the preslaughter losses.

Nevertheless, a combined analysis of all factors is still required. It is known a priori that these factors do not individually influence the losses and that the sum of some of the variables will provide information that may aid the decision-making process regarding the changes to pre-slaughter operations. In light of 
the foregoing, the aim of this study was to evaluate broiler mortality during transport at different time periods of the day when submitted to different lairage times at the slaughterhouse.

\section{Materials and Methods}

\section{General characterization of the study}

This study was conducted at a commercial broiler slaughterhouse in the State of São Paulo. The local climate is characterized as a humid subtropical climate (Cwa), according to Köppen's classification, with the temperature of the coldest month ranging between -3 and $18{ }^{\circ} \mathrm{C}$ and the temperature of the hottest month reaching above $22{ }^{\circ} \mathrm{C}$ (ALVARES et al., 2013). Additionally, a database for the year 2006 was used, containing the log data for 13,937 truckloads of poultry, including bird stocking density per crate, pre-slaughter lairage time, and the number of birds per truck.

\section{Pre-slaughter conditions}

The slaughter plant butchers on average 190 thousand broilers per day. The slaughtering starts at $5 \mathrm{~h} 30$ and ends at $3 \mathrm{~h} 30$ every day followed by cleaning of the processing platform. All the animals at the production farm are caught by the feet and then loaded into crates. The transportation crates $(0.75 \times$ $0.60 \times 0.30 \mathrm{~m})$ are made of plastic with perforations on the bottom and the sides for ventilation. Each crate can hold up to 10 birds (450 $\mathrm{cm}^{2}$ per bird). After their capture, the broilers are transported from the production farm to the slaughterhouse.

At the slaughterhouse, the trucks containing the birds are kept in a climate-controlled lairage platform, which consists of a holding area open on the sides (approximately $23.70 \times 19.22 \mathrm{~m}, 5 \mathrm{~m}$ in height) with galvanized roof tiles and six metallic trusses (Figure 1).

Figure 1. General view of the pre-slaughter environment for broiler trucks in a commercial slaughterhouse.

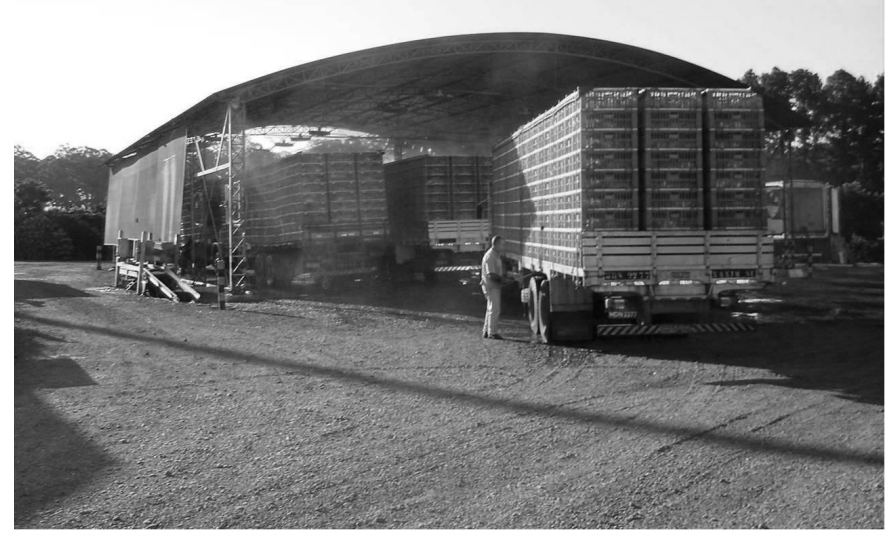

The environment temperature is controlled by fans installed on pillars and trusses (four rows with seven fans each), while eight high pressure misting sets are interspersed with the fans, each with 25 nozzles. The sides of the holding area have polypropylene panels to protect the truck's load from direct incidence of solar radiation in the summer. The lairage platform can house up to eight trucks at once, each with a transport capacity of 486 crates. After the lairage time, the trucks head to the slaughter platform. 


\section{Pre-slaughter lairage evaluation}

The response variable of this study was the preslaughter mortality for each truckload of broilers. This variable was assessed as the number of dead birds per load identified at the moment the birds were hung onto the shackles in the slaughterhouse. The main factors in this study were the time of the day (morning, afternoon, or nighttime) and lairage time. Lairage time was considered as the time between the truck's arrival at the lairage platform and the unloading of the crates onto the slaughter platform, which was categorized as short (less than 1 hour), moderate (between 1 and 2 hours), medium (between 2 and 3 hours), and long (more than 3 hours), according to the previous studies performed by Vieira et al. (2011).

The explanatory variables included in the fitted statistical model were: dry bulb temperature $\left({ }^{\circ} \mathrm{C}\right)$ and relative humidity $(\%)$ and density of broilers per crate and seasons (summer, autumn, winter, and spring). The meteorological data were obtained from the database of the "EMBRAPA Pecuária Sudeste" weather station located next to the slaughterhouse in question. The remaining data concerning pre-slaughter operations were obtained from the database of the slaughterhouse.

\section{Statistical analysis}

The data were analyzed using a double generalized linear model (DGLM), an extension of the generalized linear model (GLM), which provides a statistical modeling framework for data dispersion such as the mean. According to Smyth and Verbyla (1999), GLM traditionally considers that the mean $\mu_{i}$ can be modeled using linear link function (2):

$$
g\left(\mu_{i}\right)=x_{i}^{T} \beta
$$

where $g\left(\mu_{i}\right)$ is the logarithmic function that links the model's linear predictor and the expected pre- slaughter mortality value and is treated as a response variable with Poisson distribution. The $\beta$ vector contains the unknown regression coefficients of the explanatory factors.

DGLM assumes a second linear prediction for the dispersion (3):

$$
h\left(\phi_{i}\right)=z_{i}^{T} \lambda
$$

where $h$ is another known link function and $z_{i}$ is a covariate vector affecting the dispersion.

Similarly, the link function $h\left(\phi_{i}\right)$ was assumed as a logarithmic function, which guarantees positive values for the expected dispersion parameter $\varphi$. The Wald test was used in this study with the objective of testing the $\beta$ vector hypothesis, that is, to test the effective contribution of the factors and interactions in the statistical model (KNIGHT, 2000). This test is an extension of the Student's $t$-test, commonly used in linear regression analysis. In order to complement the Wald test, a residual analysis was performed to verify the model assumptions based on the residual deviance, adjusted values, q-q plots, scale-location plot, and Cook's distance, widely used in GLM analyses (McCULLAGH; NELDER, 1998).

The statistical software R (R DEVELOPMENT CORE TEAM, 2014) was used for model estimation along with the DGLM package (DUNN; SMYTH, 2006).

\section{Results and Discussion}

The highest temperatures were observed during the afternoon period, ranging from 24 to $35{ }^{\circ} \mathrm{C}$ (Table 1). In the morning, the average temperature was $25.3^{\circ} \mathrm{C}$, ranging from 19.5 to $31.1^{\circ} \mathrm{C}$. However, despite the significant temperature oscillation in the external environment, the temperature inside the climate-controlled lairage area of the slaughterhouse remained constant at around $22{ }^{\circ} \mathrm{C}$, due to the use of fans and misting sets. This temperature is within 
the thermal comfort limits previously established by several other authors for pre-slaughter rearing of broilers, which included the values between 18 and $24{ }^{\circ} \mathrm{C}$ (CURTIS, 1983), 21 and $23{ }^{\circ} \mathrm{C}$ (MACARI; FURLAN, 2001), and 13 and $27^{\circ} \mathrm{C}$ (SILVA, 2000).

Relative humidity in the external environment was highly variable, especially during the morning and afternoon time periods compared to the nighttime period, with standard deviation of more than $20 \%$ humidity. However, the environment surrounding the trucks had a lower variation of humidity. This is due to the aspersion of the load with the misting system, which kept the humidity at constant levels and close to saturation inside the lairage area. Such saturation of the environment with water vapor in addition to the high heat produced inside the load may lead to bird's hyperthermia. In conditions identical to the ones in the present study, the heat exchange was hampered by the respiratory evaporative cooling of around $50 \%$, which led to metabolism overload and increase of body core temperature (BALNAVE, 1998). However, if air humidity levels are low, allowing the animals to exchange heat with their surroundings through their respiratory tract, misting of the load prior to transportation on the production farms reduces preslaughter mortality (SILVA et al., 2011).

Table 1. Means and standard deviations of the environmental variables, external and internal temperature (TExt. and TInt.) and external and internal relative humidity (RHExt. and RHInt.), for different time periods of the day (morning, afternoon, and night).

\begin{tabular}{lccc}
\hline Variables & Morning & Daily Periods & Night \\
& $25.3 \pm 5.8$ & Afternoon & $23.7 \pm 2.7$ \\
TExt. $\left({ }^{\circ} \mathrm{C}\right)$ & $68 \pm 23$ & $29.8 \pm 5.8$ & $82 \pm 15$ \\
RHExt. $(\%)$ & $20.8 \pm 1.8$ & $55 \pm 21$ & $23.1 \pm 2.2$ \\
TInt. $\left({ }^{\circ} \mathrm{C}\right)$ & $86 \pm 16$ & $23.3 \pm 1.5$ & $94 \pm 8$ \\
RHInt. $(\%)$ & $95 \pm 8$ & \\
\hline
\end{tabular}

The variables that have shown significant differences $(P<0.05)$ in the average model were: temperature, lairage time, stocking density per crate, time period of the day, and the season. There was no interaction between the following variables: temperature and the afternoon period, lairage time and winter, lairage time and spring, and the afternoon period and interaction with all seasons $(P$ $>0.05$ ). The significant effects of these factors were considered in the models (mean and dispersion). In the present study, the contributions of the lairage time in a controlled environment, along with the time of the day, were demonstrated in the results and discussion section.
The interaction between the lairage time and the period of the day and their effect on the number of dead birds indicate that lairage time is a determining factor in pre-slaughter operational losses (Table 2).

It is clear that the isolated effects of each period of the day were not sufficient to explain broiler mortality during pre-slaughter operations. However, given the strong positive effect of the lairage time, the interactions involving this factor have highlighted the importance of lairage time in a climate-controlled environment.

Regarding the DGLM dispersion model, the data show that broiler transportation at noon reduced mortality by 0.085 variability units (Table 3 ). 
Table 2. Double generalized linear model for mortality estimation (number of birds per truck), given the interaction effects between the time period of the day and lairage time (mean model).

\begin{tabular}{lccc}
\hline Factors & Estimated & Standard Error & $P$-value \\
\hline Intercept & $-5.009 \times 10^{-2}$ & 0.285 & 0.860 \\
Lairage time & $3.996 \times 10^{-3}$ & $1.099 \times 10^{-3}$ & $<0.0001$ \\
Afternoon & $7.139 \times 10^{-4}$ & 0.313 & 0.998 \\
Night & 0.186 & 0.261 & 0.475 \\
Lairage time vs. afternoon & $1.243 \times 10^{-3}$ & $3.036 \times 10^{-4}$ & $<0.0001$ \\
Lairage time vs. night & $8.511 \times 10^{-4}$ & $2.243 \times 10^{-4}$ & $<0.0001$ \\
\hline
\end{tabular}

Table 3. Double generalized linear model for mortality estimation (number of birds per truck) (dispersion model).

\begin{tabular}{|c|c|c|c|}
\hline Factors & Estimated & Standard Error & $P$-value \\
\hline Intercept & 2.791 & 0.033 & 0.860 \\
\hline poli(temp) $)^{1}$ & 34.116 & 2.452 & $<0.0001$ \\
\hline poli(temp) $)^{2}$ & 26.154 & 1.559 & $<0.0001$ \\
\hline poli(temp) ${ }^{3}$ & 9.876 & 1.471 & $<0.0001$ \\
\hline Afternoon & -0.085 & 0.043 & $5.011 \times 10^{-2}$ \\
\hline Night & 0.145 & 0.031 & $<0.0001$ \\
\hline Autumn & -1.290 & 0.040 & $<0.0001$ \\
\hline Winter & -0.558 & 0.039 & $<0.0001$ \\
\hline Spring & -0.612 & 0.034 & $<0.0001$ \\
\hline
\end{tabular}

${ }^{1}$ poli(temp $)^{1,2,3}$ : third degree polynomial factors for dry bulb temperature $\left({ }^{\circ} \mathrm{C}\right)$ measured at a weather station close to the study site.

On the other hand, when the transportation was completed during the night, there was a 0.145 unit increase in mortality. In other words, pre-slaughter conditions (considering mainly the thermal factors) were more variable during the night than during the morning or afternoon. During the night, conditions of thermal comfort or stress (caused by cold or heat) may occur throughout the year. Throughout most of the year, given the high temperatures that may occur inside the load, the main stress condition during the afternoon period is the heat.

It was observed that the increase of lairage time in a climate-controlled environment during the afternoon reduced the number of dead birds, followed by the morning period. In other words, the longer the lairage time is in a climate-controlled environment, the lower the proportion of dead birds in slaughterhouses (Figure 2).

Loading during the afternoon provides the birds with higher thermal load, which remains throughout the night (BARBOSA FILHO et al., 2014). This has been confirmed in the present study, since the lairage time was not a determining factor in reducing the number of dead birds during the night. In periods with milder thermal conditions, pre-slaughter factors such as load handling or distance had little effect on mortality (SILVA et al., 2011). 
Figure 2. Interaction between the time period of the day and lairage time at the slaughterhouse, given the number of dead birds per truck. Short: less than 1 hour; Moderate: between 1 and 2 hours; Medium: between 2 and 3 hours; Long: more than 3 hours.

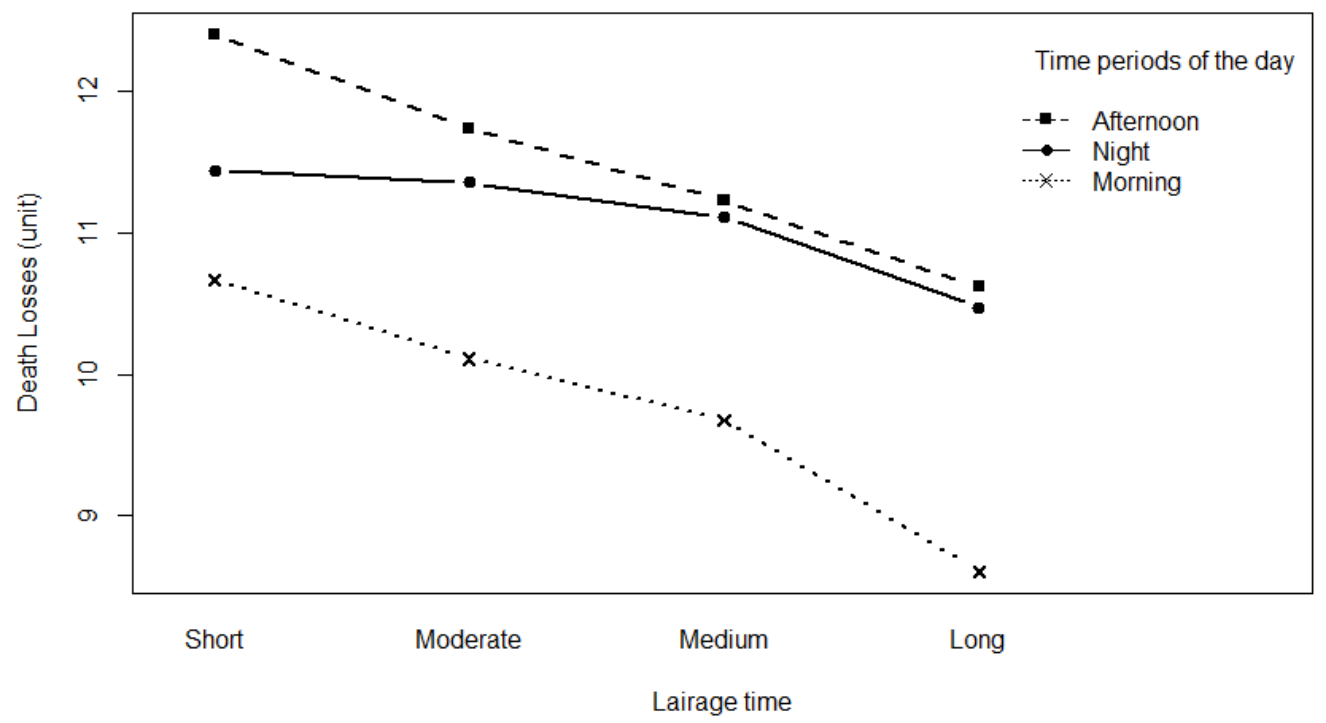

The amount of thermal energy produced by the birds is high, especially when they are transported inside plastic crates. This results in a temperature increase inside the transport crates on the truck (NIJDAM et al., 2004; SCHWARTZKOPFGENSWEIN et al., 2012). According to Silva and Vieira (2012), pre-slaughter operations prior to arrival at the slaughterhouse have unacceptable thermal conditions from an animal welfare point of view. Therefore, the birds need an optimum thermal environment during the lairage time, with enough misting and ventilation to maintain the birds' body temperature at a level that does not threaten their survival. Therefore, the results presented herein indicate that during the hotter periods of the day, the lairage environment associated with an adequate period of time is crucial in reestablishing the optimal thermal conditions of the birds.

To summarize previously discussed results, a long lairage time is recommended for loads arriving at the slaughterhouse in the afternoon, given the thermal characteristic of critical hyperthermia in birds and the need for longer lairage periods at the holding area (Table 4).

Table 4. Recommended lairage time (moderate, medium, and long) for each time period of the day (morning, afternoon, and night) and respective expected mortality percentages.

\begin{tabular}{lcc}
\hline Periods & Lairage time (time slots) & \% expected mortality \\
\hline Morning & Medium (between 2 and 3 hours) & 0.29 \\
Afternoon & Long (above 3 hours) & 0.32 \\
Night & Moderate (between 1 and 2 hours) & 0.32 \\
\hline
\end{tabular}


A medium lairage time is recommended in the morning shift, due to the transition between the night and afternoon. However, such recommendation may vary based on the external environment. During the night, if the transportation is performed under comfortable thermal conditions, a moderate lairage time is recommended, which can also be reduced in colder days.

The increase of the lairage time in a climatecontrolled environment reduced the proportion of dead birds per truckload during the hotter periods of the day, especially during the afternoon, in a subtropical climate. During the night, regardless of the chosen lairage time, no changes were observed regarding the mortality of broilers subjected to preslaughter operations.

\section{Acknowledgments}

The authors thank the Fundação de Amparo à Pesquisa do Estado de São Paulo (FAPESP) for granting the scholarship.

\section{References}

ALVARES, C. A.; STAPE, J. L.; SENTELHAS, P. C.; GONÇALVES, J. L. M.; SPAROVEK, G. Köppen's climate classification map for Brazil. Meteorologische Zeitschrift, Stuttgart, v. 22, n. 6, p. 711-728, 2013.

BALNAVE, D. Increased utilization of sensible heat loss mechanisms in high temperature, high humidity conditions. World's Poultry Science Journal, Columbus, v. 54, n. 1, p. 69-72, 1998.

BARBOSA FILHO, J. A. D.; QUEIROZ, M. L. V.; BRASIL, D. F.; VIEIRA, F. M. C.; SILVA, I. J. O. Transport of broilers: load microclimate during Brazilian summer. Engenharia Agrícola, Jaboticabal, v. 34, n. 3, p. 405-412, 2014.

BARBOSA FILHO, J. A. D.; VIEIRA, F. M. C.; SILVA, I. J. O.; GARCIA, D. B.; SILVA, M. A. N.; FONSECA, B. H. Transporte de frangos: caracterização do microclima da carga durante a estação de inverno. Revista Brasileira de Zootecnia, Viçosa, MG, v. 38, n. 12, p. 2442-2446, 2009.
BERGOUG, H.; BUREL, C.; GUINEBRETIÈRE, M.; TONG, Q.; ROULSTON, N.; ROMANINI, C. E. B.; EXADAKTYLOS, V.; MCGONNELL, I. M.; DEMMERS, T. G. M.; VERHELST, R.; BAHR, C.; BERCKMANS, D.; ETERRADOSSI, N. Effect of preincubation and incubation conditions on hatchability, hatch time and hatch window, and effect of post-hatch handling on chick quality at placement. World's Poultry Science Journal, Columbus, v. 69, n. 2, p. 313-334, 2013.

CURTIS, S. E. Environmental management in animal agriculture. Ames: The Iowa State University Press. 1983. $400 \mathrm{p}$.

DELEZIE, E.; SWENNEN, Q.; BUYSE, J.; DECUYPERE, E. The effect of feed withdrawal and crating density in transit on metabolism and meat quality of broilers at slaughter weight. Poultry Science, Savoy, v. 86, n. 7, p. 1414-1423, 2007.

DUNN, P. K.; SMYTH, G. K. DGLM: double generalized linear models. R package version 1.6.1. Vienna: R Foundation for Statistical Computing, 2006. Available at: < http://cran.r-project.org/web/packages/dglm/ dglm. pdf $>$. Accessed at: 2 fev. 2014.

KNIGHT, K. Mathematical statistics. Boca Raton: Chapman e Hall, 2000. 504 p.

MACARI, M.; FURLAN, R. L. Ambiência e produção de aves em clima tropical. In: SILVA, I. J. O. da. Ambiência e produção de aves em clima tropical. Piracicaba: Degaspari, 2001, p. 31-87.

McCUlLAGH, P.; NELDER, J. A. Generalized linear models. London: Chapman and Hall, 1989. 532 p.

NAZARENO, A. C.; PANDORFI, H.; GUISELIN, C.; VIGODERIS, R. B.; PEDROSA, E. M. R. Bem-estar na produção de frango de corte em diferentes sistemas de criação. Engenharia Agrícola, Jaboticabal, v. 31, n. 1, p. 13-22, 2011.

NIELSEN, B. L.; DYBKJÆR, L.; HERSKIN, M. S. Road transport of farm animals: effects of journey duration on animal welfare. Animal, Cambridge, v. 5, n. 3, p. 415427, 2011.

NIJDAM,E.;ARENS,P.;LAMBOOIJ,E.;DECUYPERE, E.; STEGEMAN, J. A. factors influencing bruises and mortality of broilers during catching, transport, and lairage. Poultry Science, Savoy, v. 83, n. 9, p. 1610-1615, 2004.

QUINN, A. D.; KETTLEWELL, P. J.; MITCHELL, M. A.; KNOWLES, T. Air movement and the thermal microclimates observed in poultry lairages. British Poultry Science, Edinburgh, v. 39, n. 4, p. 469-476, ago. 1998. 
R DEVELOPMENT CORE TEAM. R: a language and environment for statistical computing. Vienna: $\mathrm{R}$ Foundation for Statistical Computing, 2014. Available at: <http://www.R-project.org>. Accessed at: 2 fev. 2014.

SARNIGHAUSEN, V. C. R.; VIEIRA, F. M. C.; SILVA, I. J. O. Mineração de dados para estimativas de mortalidade pré-abate de frangos de corte. Archivos de Zootecnia, Córdoba, v. 62, n. 239, p. 469-472, 2013.

SCHWARTZKOPF-GENSWEIN, K. S.; FAUCITANO, L.; DADGAR, S.; SHAND, P.; GONZÁLEZ, L. A.; CROWE, T. G. Road transport of cattle, swine and poultry in North America and its impact on animal welfare, carcass and meat quality: A review. Meat Science, Champaign, v. 92, n. 3, p. 227-243, 2012.

SILVA, I. J. O.; VIEIRA, F. M. C. Ambiência animal e as perdas produtivas no pós-porteira: o caso da avicultura de corte brasileira. Archivos de Zootecnia, Córdoba, v. 59, n. 1, p. 113-131, 2010.

. Manejo pré-abate de frangos de corte em dias frios: os cuidados com a ambiência e bem-estar das aves transportadas durante o inverno. Thesis, São Paulo, v. 8, n. 17, p. 79-90, 2012.
SILVA, J. A. O.; SIMÕES, G. S.; ROSSA, A.; OBA, A.; IDA, E. I.; SHIMOKOMAKI, M. Manejo pré-abate de transporte e banho sobre a incidência de mortalidade de frangos de corte. Semina: Ciências Agrárias, Londrina, v. 32, n. 2, p. 795-800, 2011.

SILVA, R. G. Introdução à bioclimatologia animal. São Paulo: Nobel, 2000. 286 p.

SMYTH, G. K.; VERBYLA, A. P. Adjusted likelihood methods for modeling dispersion in generalized linear models. Environmetrics, Oxford, v. 10, n. 6, p. 695-709, 1999.

VIEIRA, F. M. C.; SILVA, I. J. O.; BARBOSA FILHO, J. A. D.; VIEIRA, A. M. C. Reducing pre-slaughter losses of broilers: crating density effects under different lairage periods at slaughterhouse. Journal of Animal Behaviour and Biometeorology, Mossoró, v. 1, n. 1, p. 1-6, 2013.

VIEIRA, F. M. C.; SILVA, I. J. O.; BARBOSA FILHO, J. A. D.; VIEIRA, A. M. C.; BROOM, D. M. Pre-slaughter mortality of broilers in relation to lairage and season in a subtropical climate. Poultry Science, Savoy, v. 90, n. 10, p. 2127-2133, 2011. 
